\title{
Anatomical variation in the innervation of the little finger: A case report
}

\author{
Pramod K Nelluri MB BS MD MCH(Plastic), Achilleas Thoma MD FRCSC FACS \\ Department of Surgery, Division of Plastic and Reconstructive Surgery, St Joseph's Hospital, McMaster \\ University, Hamilton, Ontario
}

\begin{abstract}
PK Nelluri, A Thoma. Anatomical variation in the innervation of the little finger: A case report. Can J Plast Surg 1995;3(1):47-48. The anatomy of peripheral nerves and innervation pattern in the upper extremity has been studied extensively by various authors over the decades. Anomalies and normal variations of all three major nerves have been described in the sensory patterns on both the palmar and dorsal aspect of the hand. This is a case report of a 29 -year-old male who presented with a hypothenar mass. On exploration, he was found to have an abnormal communicating branch between the palmar ulnar digital nerve to the little finger and the dorsal branch of the ulnar nerve. This anomaly has not previously been described in the literature.
\end{abstract}

Key Words: Anomalous communicating branch, Dorsal branch of ulnar nerve, Ulnar digital nerve

\section{Variation anatomique de l'innervation du petit doigt : rapport de cas}

RESUME : L'anatomie des nerfs périphériques et le mode d'innervation des membres supérieurs ont été abondamment étudiés par divers auteurs au cours des dernières décennies. Les anomalies et variations des trois principaux nerfs ont été décrites en ce qui touche aux modes sensoriels des faces palmaire et dorsale la main. Nous présentons ici le rapport de cas d'un sujet de 29 ans ayant présenté une masse à l'éminence hypothénar. L'exploration a permis de découvrir une ramification anormale entre le nerf digital cubital palmaire vers le petit doigt et la ramification dorsale du nerf cubital. Cette anomalie n'avait encore jamais été décrite dans la littérature.

A 29-year-old male patient was seen on February 12, 1992, with a large hypothenar mass which he noticed after an injury to his hand the previous year. The $6 \times 3 \mathrm{~cm}$ soft tissue mass was slightly tender to palpation and extended from the wrist to the proximal phalanx of the little finger (Figure 1). The patient was investigated with an x-ray and computerized tomographic (CT) scan which indicated a soft tissue mass not involving the bone.

At surgery, the tumour was exposed and removed through a longitudinal incision which was angulated at either end. The ulnar nerve and artery were identified proximally at Guyon's canal. The tumour measuring $6 \mathrm{~cm}$ in length was a lipoma (Figure 2), confirmed by histopathological examination. During the dissection, the ulnar digital nerve to the little finger was found to communicate with a branch arising from the dorsal sensory branch of the ulnar nerve (Figure $3)$.

Postoperatively, the sensation to the little finger was preserved intact.

Correspondence and reprints: Dr Achilleas Thoma, 200 James Street South, Suite 208, Hamilton, Ontario L8P 3A9. Telephone (905) 523-0019, Fax (905) 523-0229

\section{DISCUSSION}

In describing the ulnar nerve, a number of authors have found variations in both its motor and sensory distribution. These studies revealed that, whereas the palmar sensory digital distribution corresponded more or less with the description in anatomy textbooks $(1,2)$, the distribution on the dorsum of the hand frequently varied with few exceptions. The common variation found on the palmar aspect is the way in which the digital nerves to the adjacent surfaces of the ring and middle fingers are formed $(3,4)$. More marked variations have been reported on the dorsum of the hand. These include replacement of the dorsal cutaneous branch of ulnar nerve (DCUN) by the superficial branch of radial nerve (SRN) $(5,6)$, replacement of the SRN by both lateral antebrachial cutaneous and DCUN, or replacement of the SRN and part of the DCUN by the lateral and posterior antebrachial cutaneous nerves (6). In addition, on rare occasions, the superficial DCUN has been noted to innervate the fourth lumbrical (7). Review of the literature has not shown any reports similar to the case presented here.

Knowledge of this anomalous innervation pattern is of clinical importance. Transection of the communicating branch of the DCUN may lead to paresthesia of the little fin- 


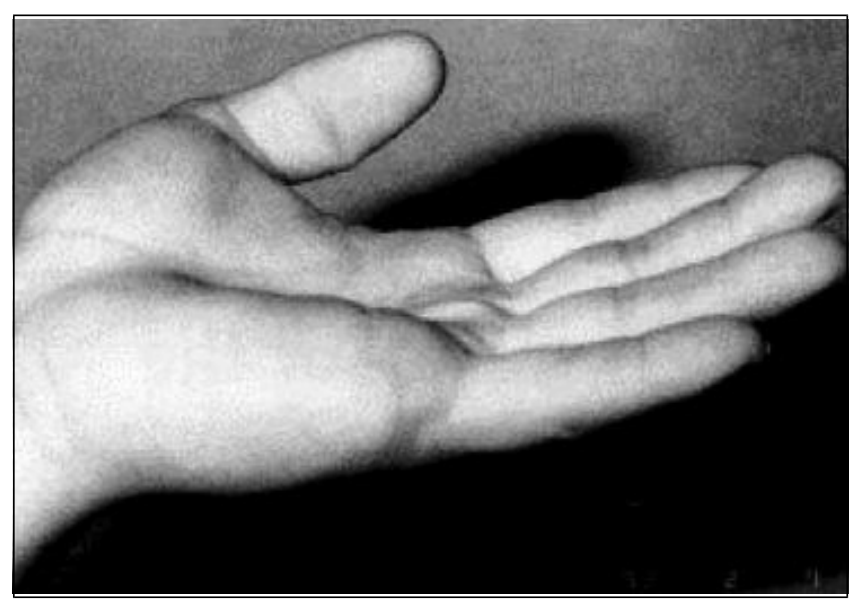

Figure 1) Soft tissue tumour in hypothenar eminence

ger,whereas complete laceration of the proper digital nerve proximal to the anastomosis may not produce complete numbness to the ulnar side of the little finger. The incidence of this communicating branch is unknown. One should be vigilant during palmar fasciectomy for Dupuytren's contracture on an abductor digiti cord since it is in this clinical scenario that this nerve variation may be troublesome.

ACKNOWLEDGEMENTS: We would like to thank Ms Beth Tadeson, BSc, for her help in the preparation and Sherry Calligan for the typing of this manuscript.

\section{REFERENCES}

1. Agur AMR, Lee MJ. Grant's Atlas of Anatomy, 9th edn. Toronto: Williams \& Wilkins, 1991:362.

2. Williams PL, Warwick R, Dyson M, Bannister LH. Gray's Anatomy, 37th edn. New York: C Livingstone 1989:1131-2.

3. Stopford JSB. The variations in distribution of the cutaneous nerves of the hands and digits. J Anat 1918;53 (Part I):14-25.

4. Linell EA. The distribution of nerves in the upper limb with reference to variabilities and their clinical significance. J Anat 1921;55:79-112.

5. Peterson AR, Giuliani MJ, McHugh M, Shipe, CC. Variations in dorso medial hand innervation, electrodiagnostic implications. Arch Neurol 1992;49:870-3.

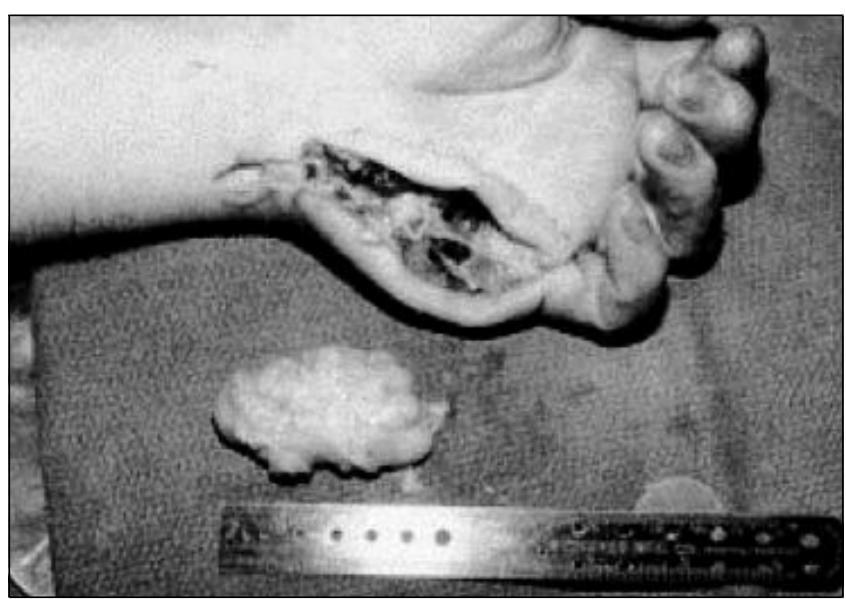

Figure 2) Lipoma, $6 \times 3 \mathrm{~cm}$

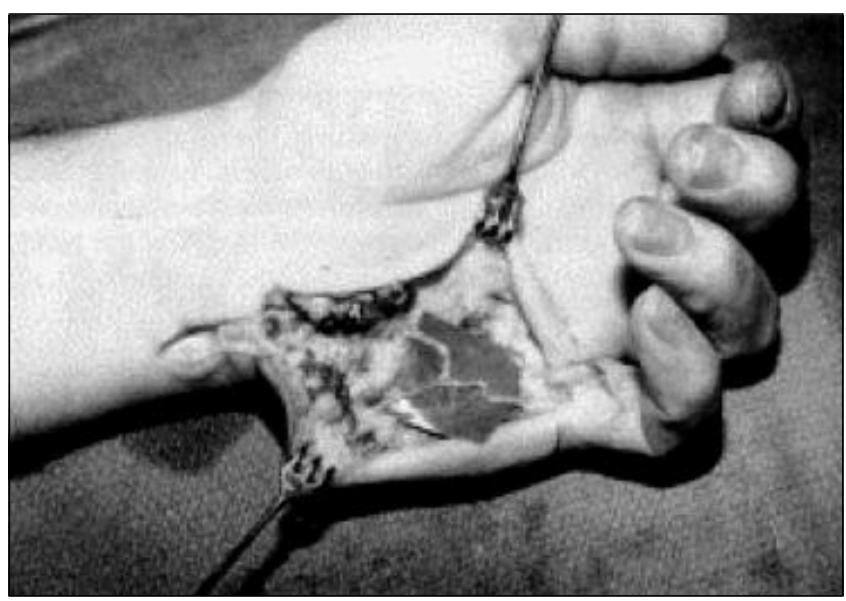

Figure 3) Ulnar digital nerve to little finger formed by palmar digital nerve and communicating branch from the dorsal ulnar cutaneous nerve (seen on top of background)

6. Hollinshead WH. Anatomy for Surgeons, 2nd edn. New York: Harper \& Row, 1969:3:540-4.

7. Matloub HS, Yousif NJ. Peripheral nerve anatomy and innervation pattern. Hand Clinic 1992;8:201-14. 